\title{
REKONSILIASI TANAH KELAHIRAN DALAM DUA PUISI IMAN BUDHI SANTOSA
}

Reconciliation to Motherland in Two Poems by Iman Budhi Santosa

\author{
Yohanes Adhi Satiyoko \\ Balai Bahasa Daerah Istimewa Yogyakarta \\ dhimassetiyoko@gmail.com
}

\begin{abstract}
Naskah diterima: 3 Desember 2018; direvisi: 31 Mei 2019; disetujui: 31 Mei 2019 doi.org/10.26499/jentera.v7i2.1063
\end{abstract}

\begin{abstract}
Abstrak: Penelitian ini membahas tentang usaha merekonsiliasi pandangan masyarakat Jawa modern terhadap tanah kelahiran yang diekspresikan dalam puisi "Ziarah Tembuni" dan "Ziarah Tanah Jawa" karya Iman Budhi Santosa. Masalah penelitian tentang fenomena sosial budaya yang tergambar dalam puisi "Ziarah Tanah Jawa" dan "Ziarah Tembuni" serta ideologi yang melandasi kedua karya puisi tersebut. Tujuan penelitian adalah menunjukkan fenomena modernitas yang dijumpai dalam masyarakat Jawa secara umum dan menunjukkan ideologi yang melandasi penciptaan puisi "Ziarah Tembuni" dan "Ziarah Tanah Jawa". Pembahasan masalah penelitian dan tujuan penelitian menggunakan metode kualitatif dengan memanfaatkan teori sosiologi Janett Wolff. Hasil penelitian membuktikan bahwa kedua ekspresi puitik dalam"Ziarah Tembuni" dan "Ziarah Tanah Jawa" menjadi ajakan rekonsiliasi untuk mengingat, mencintai, dan menyadari asal-usul kekerabatan manusia-alam dalam konstruksi sosial masyarakat Jawa. Dari hasil penelitian itu dapat disimpulkan bahwa kekerabatan dapat menghindarkan manusia dari sifat egois dan individualis. Diidealkan manusia mengalami modernitas dalam aktivitas kehidupan tetapi tetap berlandaskan pada budaya dan tradisi lokal atau bangsa sendiri.
\end{abstract}

Kata-kata kunci: rekonsiliasi, puisi, konstruksi sosial, Jawa

Abstract: This research discusses the effort of reconciliation to the Javanese people view to their land of origin as expressed in the poems "Ziarah Tembuni" and "Ziarah Tanah Jawa" by Iman Budhi Santosa. The problem formulation is how social and cultural phenomena portrayed in those poems "Ziarah Tanah Jawa" and "Ziarah Tembuni" and ideology of its creation. The purpose of the research is to show modernity phenomena as faced by Javanese people in common and show the the ideology as the foundation of the poems creation. The discussion of the problem formulation and the purpose of the research use qualitative method with sociology theory by Janet Wolff. The result shows that those two poetic expressions of "Ziarah Tembuni" and "Ziarah Tanah Jawa" sound to ask reconciliation to remind, love, and realize the origin of the kinship of mannature in the Javanese social construction. The result of the research concludes that kinship can avoid character of selfish and individualistic. Ideally, people face and experience modernity in life but they have to base it on local culture and tradition of their own country.

Keywords: reconciliation, poem, social construction, Java

How to Cite: Satiyoko, Yohanes Adhi. (2019). Rekonsiliasi Tanah Kelahiran Dalam Dua Puisi Iman Budhi Santosa. Jentera: Jurnal Kajian Sastra, 8 (1), 88-112, https://doi.org/10.26499/jentera.v8i1.1063

\section{PENDAHULUAN}

Rekonsiliasi adalah sebuah perbuatan memulihkan persahabatan ke keadaan semula (KBBI V daring). Sebuah rekonsiliasi dilakukan pada suatu kondisi tertentu, biasanya pada kondisi kritis. Rekonsiliasi kepada tanah kelahiran adalah se- 
buah ajakan bagi individu atau sekelompok orang untuk kembali bersahabat dengan keadaan sosial budaya dan kerabat seperti yang pernah dijalani oleh mereka semasa kecil atau semasa nenek moyang mereka. Pola kehidupan modern dan tradisional adalah dua karakter tata kehidupan sosial budaya yang berbeda dan perlu kesiapan sikap dan mental untuk menjalaninya.

Pola kehidupan modern tidak dapat dilepaskan dari aktivitas pergerakam masyarakat urban, perpindahan masyarakat dari daerah pinggiran ke kota besar. Jakarta adalah salah satu ikon kehidupan modern dengan pola tatakota yang metropolis. Masyarakat urban dikatakan sebagai kelompok masyarakat yang mempunyai tradisi atau kebiasaan tertentu. Pengertian urban terletak pada perbedaan sifat kehidupan dengan masyarakat pedesaan, seperti kehidupan religi dan keagamaan yang berkurang, cara berpikir rasional yang mengedepankan perhitungan eksak. Cara berpikir rasional ini disebabkan karena mereka hidup dan beraktivitas di dalam ranah kehidupan yang berdasarkan prinsip ekonomi dan perdagangan. Selain itu, masyarakat urban cenderung mengurus kepentingannya sendiri-sendiri sebagai individu (individualis). Implikasinya adalah kehidupan keluarga dan kekerabatan terkadang sukar dipersatukan karena kepentingankepentingan individu yang berbeda. Di samping itu latar pendidikan juga membedakan tingkah laku dan kebutuhan hidup tiap individu yang mengerucut pada munculnya kelompok-kelompok kecil sesuai bidang keahlian mereka. Berikutnya adalah jalan pikiran yang rasional yang menyebabkan setiap individu memperhitungkan waktu demi mengejar kebutuhan individual mereka (Soekamto, 2002: 139-140; dalam Purwantini, 2016:164).

Indonesia sebagai negara agraris masih dominan memegang teguh adatistiadat serta budaya kekerabatan yang erat. Namun, terjangan modernisasi dalam gelombang globalisasi mempunyai iming-iming tersendiri bagi sebagian masyarakat untuk mengimitasinya dan menjadi bagian dari modernitas tersebut. Di sisi lain, sebagian masyarakat urban, yang berpindah dari desa ke kota mengalami gegar budaya (cultural shock). Hal ini terjadi karena mereka berada dalam lingkungan baru yang berbeda dari tempat asal mereka di negerinya sendiri (intranasional). Keadaan ini dipicu oleh rasa cemas yang muncul karena mereka kehilangan tanda serta hubungan sosial yang sudah lama dikenal atau familiar dalam 
lingkungan dan interaksi sosial di tempat mereka sebelumnya. Tanda-tanda tersebut adalah petunjuk dalam bentuk kata-kata, isyarat-isyarat, ekspresi wajah, kebiasaan-kebiasaan, serta norma-norma yang diperoleh individu sepanjang kehidupan mereka di tanah asal atau kelahiran (Mulyana, 2016: 175; dalam Devinta, Hidayah, dan Hendrastomo, 2015:4). Secara tersirat, pernyataan Mulyana (2016) menegaskan bahwa kehidupan di tanah asal atau tanah kelahiran telah membentuk adat kebiasaan individu yang berkerabat mendalam secara sosial budaya. Adaptasi terhadap budaya urban akan menggerus sikap berkerabat yang pernah dilakoni oleh individu di daerah asalnya.

Indonesia diibaratkan sebagai jagat ageng atau dunia besar dan berbagai suku bangsa dengan daerah tempat tinggal mereka sebagai jagat alit atau dunia kecil. Jagat Jawa sebagai salah satu jagat alit mempunyai masyarakat yang harus menjawa (seperti juga mengindonesia). Jangan sampai muncul ungkapan "orang Indonesia hilang keindonesiaannya" seperti di Jawa "wong Jawa ilang Jawane" karena mengimitasi modernitas secara tidak tepat. Jawa adalah Indonesia, seperti juga Bali, Papua, Aceh, Kalimantan adalah Indonesia, maka membangun masyarakat Jawa adalah juga membangun masyarakat Indonesia. Maka, sikap handarbeni atau memiliki perlu ditanamkan dalam ranah kedaerahan terlebih dahulu (jagat alit). Kesadaran akan jati diri sebagai orang Jawa (juga suku bangsa lain di Indonesia dalam kerangka nasional) perlu dimunculkan dan dimaksimalkan untuk membangun tanah kelahiran (Satiyoko, 2012: 248).

Sastra sebagai sebuah produk masyarakat (social production of art) mempunyai peran penting dalam mengevaluasi tata kehidupan masyarakat tersebut. Karya sastra hadir sebagai social production of art, yaitu hasil karya yang berdasarkan latar sosial budaya masyarakat tertentu. Dengan demikian, karya sastra merupakan elemen rekonsiliasi bagi masyarakat, selain arena untuk apresiasi isi karya sastra tersebut. Karya sastra hadir sebagai evaluator sosial budaya yang menyuguhkan gambaran masyarakat sejujurnya. Puisi adalah salah satu jenis karya sastra yang mampu memberi evaluasi estetik terhadap kehidupan masyarakat. Karya-karya puisi Iman Budhi Santosa adalah satu dari sekian banyak karya sastrawan yang berkredo tentang kekerabatan dan hubungan manusia dengan alam, khususnya Jawa. "Ziarah Tanah Jawa” dan "Ziarah Tembuni” adalah dua 
dari karya Iman Budhi Santosa yang secara tegas menyuarakan rekonsiliasi dengan tanah kelahiran, yaitu Jawa. "Ziarah Tanah Jawa” dan "Ziarah Tembuni” dimuat dalam buku Narasi Tembuni, Kumpulan Puisi Terbaik KSI Award 2012 Komunitas Sastra Indonesia. Penelitian ini sedikit banyak menyambung nada keprihatinan dan kerinduan terhadap tanah tumpah darah, khususnya Jawa, seperti penelitian terdahulu tentang "Wong Jawa" dalam geguritan "Serere Adhuh Lae" karya Turiyo Ragilputro dan "Siter Gadhing” karya Djaimin Kariyodimejo" yang dilakukan oleh Satiyoko (2012). Dalam penelitian tersebut tersirat kecaman dan satire terhadap gaya hidup masyarakat desa yang sok kekota-kotaan (sindiran kepada pemuda yang hijrah ke kota dan melupakan berbagai tata kehidupan budaya desa dengan berbagai karakternya).

Masalah yang diangkat dalam penelitian dipilah menjadi dua, 1) bagaimanakah gambaran atau fenomena sosial budaya masyarakat Jawa yang tergambar dalam puisi "Ziarah Tanah Jawa" dan "Ziarah Tembuni" yang terimbas kehidupan modernitas dan globalisasi, 2). Apa ideologi penciptaan kedua puisi Iman Budhi Santosa, "Ziarah Tanah Jawa" dan "Ziarah Tembuni". Kedua masalah tersebut diuraikan dalam tujuan penelitian, yaitu untuk 1) Mmenunjukkan fenomena sosial budaya masyarakat Jawa dalam arus modernitas melalui pemaparan latar sosial budaya interaksi sosial pengarang dengan lingkungan sosialnya dan 2) menunjukkan ideologi penciptaan puisi "Ziarah Tanah Jawa" dan "Ziarah Tembuni".

\section{LANDASAN TEORI}

Pembahasan dalam penelitian ini menggunakan teori sastra verstehen Janet Wolff (1975). Kajian sosiologi verstehen atau fenomenologis digunakan oleh Wolff untuk menunjukkan metode kajian sosiologi yang digunakannya dengan dasar fenomenologi pengetahuan. Terminologi verstehen berasal dari bahasa Jerman yang berarti understanding atau pemahaman. Di dalam kajian sosiologi, pemahaman yang dimaksud adalah pemahaman mengenai individu dalam kehidupan sosialnya (Wolff, 1975: 4-6).

Wolff membagi pembicaraan sesuai dengan proses berpikir fenomenologi pengetahuan, yaitu (a) fenomenologi pengetahuan dan konstruksi sosial dunia, (b) 
bahasa dan pengetahuan tentang dunia, dan (c) pengetahuan perhatian dan ideologi. Tahap fenomenologi pengetahuan dan konstruksi sosial dunia bertitik tolak dari lebenswelt sebagai kerangka kerjanya (point of reference). Lebenswelt atau dunia kehidupan sosial merujuk pada lingkungan sosial budaya tempat individu melakukan aktivitas sehari-hari (Wolff, 1975: 12). Dengan demikian, tahap pertama ini pembahasan berfokus pada dunia sosial budaya tempat individu pengarang tinggal dan beraktivitas sebagai anggota masyarakat. Gambaran lebenswelt (dunia kehidupan sehari-hari) dianggap mampu memberikan pengetahuan yang berasal dari masyarakat, terlepas dari kesahihan atau ketaksahihan pengetahuan tersebut (Berger, 1990: 4).

Tahap Bahasa dan Pengetahuan Dunia mengupas pengalaman individu secara subyektif dan obyektif. Pengalaman subyektif individu tersebut oleh Wolff disebut sebagai experiential biography atau dikatakan Wolff sebagai mode of experience grounded. Pengalaman subyektif individu didasarkan pada aktivitas sehari-harinya berinteraksi dengan masyarakat tempat dia tinggal dan dalam waktu tertentu. Pengalaman, pikiran, ide dan gagasan pengarang diekspresikan melalui ekspresi bahasa dalam karyanya. Bahasa yang diekspresikan oleh individu dalam sebuah media ekspresi (karya sastra sebagai produk sosial) mampu menjadi tempat penyimpanan yang obyektif dari akumulasi makna dan pengalaman yang besar sekali dan yang kemudian dapat dilestarikan dalam waktu dan diteruskan kepada generasi berikutnya (Berger, 1990: 53). Kemampuan bahasa seperti dipaparkan Berger berimplikasi pada manfaat bahasa sebagai alat komunikasi antara pengarang dan pembaca sehingga dapat diperoleh pemahaman mengenai maknamakna, yang secara simbolis (tipifikasi atau perlambangan) dalam ekspresi kesastraannya, dibuat oleh pengarang dalam sebuah karya sastra. (Wolff, 1975:30).

Tanda mempunyai tujuan untuk menunjukkan makna subyektif dari orang yang membuatnya. Secara objektif, tanda dalam kenyataan bersama dialami oleh dia, saya, dan orang lain (Berger 1990: 51). Pemahaman mengenai makna di balik tanda-tanda yang diketahui melalui tindakan sosial harus memenuhi syarat, yaitu pemahaman terhadap bahasa. Syarat tersebut dikemukakan oleh Weber dan Schutz (dalam Wolff, 1975: 21). Selanjutnya, metode verstehen dalam kajian so- 
siologi pengetahuan Wolff mensyaratkan pemahaman bahasa dan gaya berbicara subjek (Wolff, 1975: 30). Bahasa seorang subjek mempertahankan dan mengekspresikan kenyataan, lebih dari sekadar sebuah kreasi. Maka, pemahaman mengenai bahasa merupakan syarat paling dasar untuk memahami kenyataan dalam kehidupan sehari-hari individu pengarang (Wolff, 1975: 30).

Tahap ketiga adalah pengetahuan dan ideologi yang menghasilkan simpulan dari tafsir sosial dalam tipifikasi melalui bahasa ekspresi karya sastra yang terstruktur. Simpulan tersebut merupakan buah ideologi yang menjadi sebuah pengetahuan dalam kerangka dunia sosial (Wolff, 1981:51). Ideologi (Bullock, 1988: 404) hadir sebagai sebuah penegasan tentang berbagai hal khusus yang menjadi daya tarik (interest) dalam kehidupan sosial. Lebih lanjut, Wolff merinci uraian mengenai ideologi, yaitu usaha mengungkap hakikat kenyataan dari realita sosial ekonomi dan politik dengan sistem representasi yang dinyatakan dengan gagasan atau ide yang tidak berdiri sendiri dari kondisi material yang ada tetapi terstruktur dan tersistem. Jadi, ideologi sebagai representasi ide atau gagasan individual yang menyuarakan hakikat manusia dalam interaksi sosial mereka didasari oleh latar sosial kehidupannya. Tujuan kajian sosiologi verstehen adalah menunjukkan hakikat kemanusiaan (the nature of mankind), yaitu individu dan dunia sosialnya.

Ideologi yang diekspresikan oleh Iman Budhi Santosa yang menggambarkan sisi humanitas atau kemanusiaan terlihat dari upayanya menerbitkan banyak karya sastra. Sebagai sebuah ekspresi yang berlandaskan fenomena sosial yang dijumpainya, Iman tidak mencari laba sebagai sulih hasil cipta kepengarangannya. Sastra digunakannya sebagai sarana mengekspresikan kegelisahan yang berkontribusi pada kemanusiaan, sekaligus ekspresi spiritualnya (Safitri, 2015:130). Kajian tersebut menunjukkan perjalanan Iman Budhi Santosa sampai memperoleh posisi terkonsentrasi dalam arena sastra dalam tulisan Safitri (2015) berjudul "Pergulatan Iman Budhi Santosa untuk Mencapai Posisi Terkonsentrasi dalam Arena Sastra Yogyakarta."

Sisi kemanusiaan Iman Budhi Santosa juga pernah dibedah dalam disertasi karya Dian Lufia Rahmawati dan disajikan dalam buku berjudul Jiwa Puisi. PuisiPuisi Iman Budhi Santosa dalam Pendekatan Psikofilosofi Berdsarkan Perspektif 
Ki Ageng Suryomentaram. Diterbitkan oleh Interlude tahun 2019. Rahmawati (2019) menunjukkan sisi kemanusiaan dalam praktik ekspresi sastra dan filosofi psikologis manusia berdasarkan pemikiran Ki Ageng Suryomentaram dalam kerangka kehidupan dan pola pikir masyarakat Jawa.

Penelitian tentang dua puisi Iman Budhi Santosa ini merupakan upaya memperkaya data tentang ideologi kepengarangannya yang berupaya mengangkat humanitas dan mengesampingkan capaian kapital semata. Ziarah Tembuni dan Ziarah Tanah Jawa diuraikan dalam penelitian ini sebagai dua buah puisi yang bernalogi tentang kehidupan orang-orang Jawa di desa. Di sisi lain kedua puisi tersebut diekspresikan Iman sebagai ibarat sampiran dan isi dalam sebuah ekspresi pantun.

\section{METODE PENELITIAN}

Penelitian ini menggunakan metode deskriptif kualitatif sesuai dengan masalah yang telah dirumuskan. Penelitian kualitatif merupakan penelitian yang temuannya tidak diperoleh melalui prosedur statistik (Strauss dan Corbin, 2013:4-5; dalam Lestari, dkk., 2018:183). Penelitian kualitatif bermaksud memahami fenomena yang dialami subjek dengan cara deskripsi dalam bentuk kata-kata dan bahasa pada konteks khusus dengan memanfaatkan metode ilmiah.

Sumber data adalah dua puisi karya Iman Budhi Santosa berjudul "Ziarah Tembuni” dan "Ziarah Tanah Jawa" yang dimuat dalam Narasi Tembuni. Kumpulan Puisi Terbaik KSI Award 2012 Komunitas Sastra Indonesia, diterbitkan atas kerja sama Komunitas Sastra Indonesia (KSI) dan Badan Pengembangan dan Pembinaan Bahasa, tahun 2012. Data penelitian ini adalah kata-kata, frasa, klausa, kalimat yang terdapat dalam kedua puisi tersebut. Analisis data dilakukan dengan menggunakan teori sosiologi verstehen Verstehen Janet Wolff (1975).

Pembahasan dalam analisis dibagi menjadi tiga tahap sesuai dengan kerangka teoretis Wolff. Pertama adalah pembahasan tentang fenomena sosial budaya masyarakat Jawa. Tahap ini menguraikan pandangan fenomena sosial budaya tempat pengarang tinggal sebagai anggota masyarakat. Pembahasan tentang subjek pengarang (Iman Budhi Santosa) dalam dunia sosialnya (Yogyakarta), tempat dia hidup, berkarya sebagai sastrawan, dan mengkritisi fenomena moderni- 
tas dalam budaya masyarakat Jawa. Ini adalah sebuah cara verstehen, yaitu memberikan pemahaman yang sahih atas kenyataan terhadap fenomena dan individu yang mengalaminya (mode of experience grounded). Berikutnya adalah pembahasan tentang bahasa dan pengetahuan dunia. Tahap ini membahas tentang penggunaan bahasa atau ekspresi sebagai perlambangan atau tipifikasi dalam puisi “Ziarah Tanah Jawa” dan "Ziarah Tembuni” yang dicipta oleh Iman Budhi Santosa. Ekspresi kebahasaan dengan diksi yang beridiom Jawa menjadi fokus pembahasan. Tahap terakhir adalah tahap pengetahuan dan ideologi. Tahap ini menjadi tahap tafsir terhadap tipifikasi atau perlambangan yang menjadi ideologi kepengarangan Iman Budhi Santosa dalam puisi "Ziarah Tembuni” dan "Ziarah Tanah Jawa" yang menjadi pengetahuan baru bagi masyarakat pembaca.

\section{PEMBAHASAN}

\subsection{Modernitas dalam Budaya Jawa}

Konsep fenomena sosial dan konstruksi sosial menurut Wolff (1975) mengambil sudut pandang lingkungan sosial budaya tempat pengarang hidup. Wolff mengutip ungkapan Spielberg dalam, glossary of phenomenological terms mengenai Lebenswelt atau dunia kehidupan, yaitu kehidupan mempunyai beragam dinamika yang dapat ditangkap oleh panca indera dan dialami oleh manusia. Lebih lanjut Wolff menyatakan bahwa untuk mewujudkan sebuah dunia sosial (lebenswelt) yang objektif diperlukan model semacam pengalaman individu (mode of experience grounded) pengarang (Schultz, 1967 dalam Wolff, 1975: 16). Lebenswelt diperoleh karena pengarang mengalami sendiri apa yang ditulisnya. Pengalaman ini membuka cakrawala baru mengenai sebuah dunia yang hidup dengan berbagai fenomena kemanusiaannya. Konsep fenomenologi dalam sosiologi Verstehen mengambil Lebenswelt sebagai point of reference (Wolff, 1975:14). Pengalaman yang dimaksud bukanlah pengalaman yang kebetulan, tetapi suatu bentuk pengalaman yang mempunyai arti bagi pengalaman (author) yang ditafsirkan dalam konteks keberadaan dunia kehidupan yang dihadapi pengalam (existing life-world) (Wolff, 1975: 16).

Ketika seorang pengarang menulis mengenai satu dunia, tulisan tersebut didasari oleh pengalaman yang benar-benar pernah dialaminya, bukan didasarkan 
pada kajian pustaka (library research). Uraian tersebut menunjukkan pentingnya peran kesadaran (consciousness) seorang individu (author) untuk terlibat dan berinteraksi dengan masyarakat tempat dia tinggal. Dengan kesadaran (consciousness), pengalaman yang direkam seorang individu tidak bersifat kebetulan (contingent fact) tetapi benar-benar dikehendaki oleh individu tersebut untuk diketahui. Inilah yang disebut oleh Schultz dengan mode experience grounded. Dasar pemahaman inilah yang menjadi landasan utama fenomenologi yang berusaha mengungkap keseluruhan pengalaman hidup pengarang dalam dunia yang menyimpan arti (meaningful world). Dalam hal ini dijelaskan tentang fenomena modernitas, implikasinya, dan tanggapan pengarang (Iman Budhi Santosa) terhadap dunia yang dihadapinya.

Fenomena modernitas dapat dilihat dari berbagai sisi kehidupan, seperti saat ini sudah muncul revolusi industri 4.0. Era industri ini memandang teknologi informasi menjadi basis dalam kehidupan bermasyarakat. Penggunaan perangkat komputer dan data yang tidak terbatas akibat perkembangan internet dan teknologi digital yang masif sebagai tulang punggung pergerakan dan jejaring koneksi manusia dan mesin mengakibatkan segala informasi dan komunikasi berjalan tanpa batas, tanpa harus hadir dan bertatap muka langsung. Era seperti ini berimbas pada disrupsi aneka aktivitas pengetahuan, seni, budaya, pendidikan, serta kekerabatan manusia (Suwandi, 2018: 2).

Lebih lanjut, konsep revolusi industri ini memodernkan segala aspek kehidupan yang bermuara pada efektivitas, produktivitas, dan individualitas. Dasar perkembangan ekonomi, teknologi, dan kapital adalah tujuan yang harus dipenuhi dalam era modern seperti ini. Pada konteks revolusi industri tersebut, proses yang terjadi adalah perubahan sosial dan budaya yang berlangsung secara cepat dan menyangkut kebutuhan mendasar atau pokok manusia. Perubahan tersebut terjadi karena direncanakan atau tidak direncanakan (Suwardana, 2017:103). Kota industri adalah arena berkembangnya dan berprosesnya modernitas yang berbasis teknologi. Jakarta, sebagai kota metropolitan dan ibukota negara merupakan ikon perkembangan teknologi dan industri di Indonesia. Sebagai ibukota, Jakarta menawarkan segudang gaya hidup yang modern, yang berkiblat pada budaya barat sebagai kiblatnya (western culture). Dengan demikian, Jakarta menjadi kota ur- 
ban, kota tujuan para pendatang dari daerah atau Jawa (sebutan untuk daerah di Jawa selain Ibukota Jakarta). Jadi, ketika terjadi urbanisasi dari Yogya ke Jakarta dikatakan dari Jawa ke ibukota. Sebaliknya ketika pulang dari Jakarta ke Yogyakarta, orang-orang mengatakan pulang ke Jawa.

Budaya urbanisasi terkadang terjadi tidak berpola. Setiap kali orang desa yang telah bekerja di kota kembali ke desa, mereka akan mengajak teman-teman mereka di desa untuk "meraih mimpi" di kota. Momen hari besar, seperti lebaran dan tahun baru menjadi titik urbanisasi besar-besaran. Impian akan kehidupan yang lebih mudah, menyenangkan, dan menghasilkan uang telah mengaburkan akal sehat kaum urban sehingga banyak orang yang berangkat menuju ibukota tanpa "bekal" yang memadai untuk hidup dan bekerja. Ketidaksiapan hidup di kota dengan berbagai kompleksitas permasalahannya membuat orang-orang urban tidak mampu mengendalikan keteraturan dan keseimbangan pikiran, perasaan, dan perbuatan mereka. Pengangguran adalah akibat nyata dari ketidaksiapan keahlian (skill) kaum urban. Tentunya, pengangguran akan mengarah kepada kemiskinan, bahkan kriminalitas.

Fenomena modernitas tidak saja terjadi melalui urbanisasi, tetapi juga penggunaan peranti komunikasi yang terus berkembang dan semakin canggih. Tidak berbeda dengan urbanisasi, kemajuan teknologi mampu mengalienasi individu dan lingkungan sosial budayanya. Urbanisasi menjauhkan jarak antarindividu karena letak geografis, sedangkan penggunaan peranti komunikasi modern, seperti gadget, tablet, smartphone menjauhkan individu dari komunikasi verbal, interaksi fisik, dan kekerabatan. Aneka aktivitas berinteraksi dan berkerabat sudah diwakili oleh peranti tersebut yang dapat dioperasikan di mana saja tanpa perlu berpindah tempat. Aktivitas seperti itu menimbulkan sikap dan sifat egois; kurang perhatian terhadap sesama.

Modernitas adalah sebuah keniscayaan dalam kehidupan, tetapi modernitas yang merasuk dalam alam pikir individu atau masyarakat diharapkan tetap mampu menyejajar dengan tradisi dan budaya setempat. Hal ini dapat menghindarkan masyarakat dari gegar budaya. Beragam aktivitas budaya dan tradisi memudar ketika tatap muka dan kehadiran untuk sowan kepada orang tua atau sesepuh sudah digantikan dengan tulisan dan gambar di whatsapp, facebook, 
instagram, atau media sosial lain yang serupa. Ucapan selamat hari raya kepada kerabat dan handai taulan sudah tidak lagi diwakili dengan jabat tangan, tetapi melalui representasi ikon-ikon di media sosial. Terlepas dari efektivitas dan acuan kapital, banyak aktivitas kekerabatan dan budaya masyarakat Jawa mulai memudar. Sekarang sangat jarang dijumpai aktivitas rewang (gotong royong membantu) untuk membantu keluarga yang punya hajat. Lebih praktis keluarga tersebut memanfaatkan jasa event organizer. Tradisi ruwahan menjelang puasa pun sekarang mulai tidak terlihat. Tidak ada lagi keluarga yang membuat apem, ketan, kolak yang diberikan kepada tetangga. Kalau pun ada sesajian tersebut dibuat instan, dengan memesan kepada penjual makanan. Memudarnya tradisi kenduri untuk merayakan atau mengenang seseorang yang sudah meninggal. Menengok leluhur di makam pada bulan ruwah (kalender Jawa) pun jarang dilakukan, khususnya generasi muda. Tradisi berkumpul, berkerabat, dan saling memberi perhatian sudah mulai pudar seiring kebutuhan hidup yang berkiblat pada modernitas yang mengedepankan efektivitas, efisiensi, dan individual. Kiblat modernitas adalah kiblat industrialis-teknologis yang mengedepankan kebangunan fisik secara dominan. Tidak heran jika kemudian muncul alienasi terhadap budaya lokal. Yogyakarta sebagai bagian dari daerah lokal Jawa tidak lepas dari pengaruh globalisasi yang modern.

Yogyakarta adalah salah satu kota dengan tradisi budaya Jawa yang dianggap masih kuat. Sebagai salah satu kota tujuan wisata dan kota pelajar, Yogyakarta menjadi penumpu industri kreatif budaya dan tradisi. Namun, globalisasi telah mengubah konstelasi kebudayaan. Usaha ekonomi yang memproduksi barang kebudayaan sudah tergantikan oleh dan dikuasai oleh industri asing. Kuliner asing, seperti hamburger, hot dog dengan industri waralabanya, Mc.Donalds, Kentucky Fried Chicken sudah memarjinalkan kesukaan masyarakat mengunsumsi geplak, thiwul, gatot, cenil, serta jajan pasar lainnya. Pakaian tradisional, permainan tradisional sudah mulai ditinggalkan, kalah oleh gaya pakaian dari luar negeri dan game-game yang sangat mudah diunduh dari application store melalui aplikasi android (Soeroso dan Susilo, 2008:145). Rekaman atas dinamika perkembangan modernitas dan globalisasi juga dicatat dan dialami sendiri oleh Iman Budhi Santosa, seorang sastrawan yang bergelut dengan dunia sastra Yog- 
yakarta. Model pengalaman individu (mode of experience grounded) yang disyaratkan oleh Schultz (1967) dalam Wolff (1975: 16) terpenuhi dengan merujuk kepada dunia social (lebenswelt) yang objektif dari aktivitas bersastra Iman Budhi Santosa sejak hijrahnya ke Yogyakarta, melakoni aktivitas sastra dengan Persada Studi Klub (PSK) bersama Umbu Landhu Paranggi, sampai sekarang (2019) tetap menyuarakan sastra bertema sosial kemanusiaan.

Iman Budhi Santosa adalah seorang yang lahir dari keluarga priyayi di Magetan, Jawa Timur. Sejak kecil, kakek Iman memberi pengaruh kuat kepadanya tentang pentingnya mencatat dan menulis semua hal yang dia jumpai. Berbagai pertanyaan sederhana dilontarkan kepada Iman untuk mengasah pikiran kritis dalam menjawab berbagai fenomena sosial budaya di sekitarnya. Pertanyaan tentang di mana kuburan burung yang mati tanpa dibunuh ditemukan, dan menapa kucing mati secara alami tidak berada di sembarang tempat. Pengondisian pemikiran kritis yang terbina sejak kecil tersebut akhirnya terbawa oleh Iman Budhi Santosa sampai dewasa dengan mencermati, mengobservasi, mencatat, dan mengevaluasi secara kritis keadaan yang dijumpainya. Aktivitas menulis Iman, yang juga dipupuk dan dipengaruhi oleh ibunya mengerucut pada ekspresi kesastraan yang akhirnya mentahbiskannya menjadi seorang sastrawan yang kritis. Kekritisan Iman dalam melihat fenomena sosial budaya membawanya pada kepedulian terhadap alam sekitar dan kekerabatan manusia (Safitri, 2015:126127).

Perjalanan hidup bagi Iman Budhi Santosa akhirnya menempatkannya sebagai sastrawan yang berpengaruh dan senior di Yogyakarta. Yogyakarta merupakan sebuah arena yang masih mempunyai kekerabatan yang kuat, sebuah kota dengan masyarakat yang dikatakan pinggiran jika disejajarkan dengan modernitas masyarakat urban. Ada magnet kekerabatan yang kuat dan mengakar di kota Yogyakarta. Maka, aktivitas kesastraan Iman sewaktu masih aktif di Persada Studi Klub (PSK) bersama Umbu Landhu Paranggi adalah melihat masyarakat pinggiran atau marginal yang dijumpainya. Malioboro adalah salah satu arena studi Iman melihat masyarakat marjinal, seperti tukang becak, gelandangan, serta pengemis. Tiada lain, aktivitas Iman adalah sebuah proses mengasah imaji dan hati untuk tetap mengakar pada kekerabatan (Safitri, 2015:128). Prinsip niteni, eling 
lan waspada serta eling marang sangkan paraning dumadi selalu menginspirasi Iman Budhi Santosa dalam mencipta karya-karyanya.

Dalam perjalanan hidup, Iman juga menghadapi berbagai pengalaman spiritual, sosial, kekerabatan, bahkan yang juga dialaminya di dalam keluarga. Iman banyak melihat sisi humanis manusia dalam perjalanan hidup, pekerjaannya yang bersinggungan dengan pegawai negeri sipil serta perkebunan dan hutan sehingga memunculkan ekspresi spiritual dalam petuah-petuah hidup yang mewarnai karya kepenyairannya. Tradisi mencatat di masa kecil telah mengantarkan Iman untuk mengekspresikannya melalui ranah estetis, yaitu kepenyairan. Catatan adalah jejak tapak yang menyadarkannya. Memperkaya diri melalui berbagai komunitas sastra, seperti keterlibatannya dalam PSK di Malioboro tahun 1969 dan komunitas-komunitas sastra sampai sekarang telah mengantarkan Iman menjadi "buku berjalan" di ranah sastra Yogyakarta (Santosa, 2016: 333-341). Kekayaan bekal sosial budaya Iman Budhi Santosa inilah yang mentahbiskannya menjadi seorang sastrawan senior di Yogyakarta.

Perhatian dan keprihatinan terhadap kekerabatan yang semakin tergerus oleh modernisasi terekspresi melalui berbagai karya sastranya, di antaranya Dunia Batin Orang Jawa (2007), Budi Pekerti Bangsa (2008), 3 Cerita Anak Keislaman (2008), Peribahasa Indonesia (2009), Nguri-Uri Paribasan Jawi (2010), Nasihat Hidup Orang Jawa (2010), Laku Prihatin, Investasi Menuju Sukses ala Manusia Jawa (2011), Petuah-petuah Bijak Leluhur Nusantara Seputar Perkawinan (2011), Saripati Ajaran Hidup Dahsyat dari Jagat Wayang (2011), Ziarah Tanah Jawa (2013), Manusia Jawa Mencari Keheningan Hati (2014), Sesanti Tedhak Siti (2015), Peribahasa Nusantara, Mata Air Kearifan Bangsa (2016), Suta Naya Dhadhap Waru: Manusia Jawa dan Tumbuhan (2017). Selain karya sastra, Iman Budhi Santosa juga dipercaya menjadi anggota Dewan Kebudayaan Kota Yogyakarta (DKKY) seksi bahasa dan sastra Jawa, menerbitkan majalah Sabana (2013), menerima penghargaan sebagai Penggerak Sastra Indonesia dari Balai Bahasa Yogyakarta (2009), KSI Award (2012), Anugerah Sastra dari Pemprov DIY (2013), Anugerah dari YASAYO (2015), dan penghargaan lainnya.

Berbagai pencapaian dan penghargaan menjadi motor penggerak kreativitas Iman Budhi Santosa. Dengan mengikuti perkembangan zaman, modernitas, 
dalam kacamata Iman Budhi Santosa merupakan suatu gaya hidup baru yang dirombak dari nilai-nilai tradisi dan adat kebiasaan warisan nenek moyang, yang dirasa "ketinggalan zaman" (2018:60). Hijrah menuju ke kehidupan urban mempunyai sisi negatif dan positif sebagai konsekuensi sebuah kemajuan "peradaban". Tarik-menarik antara desa kota sudah tidak berimbang lagi karena lebih banyak tawaran visual dan fisik yang menyenangkan di kota daripada tawaran desa yang monoton dan tradisional. Namun, di balik modernitas tersebut, ternyata kemajuannya tidak diimbangi dengan kematangan mental sehingga sebenarnya banyak timbul kegagalan dalam kehidupan para kaum urban dan calon-calon urban. Kegagalan inilah yang sering mengemuka dan menimbulkan berbagai akibat yang bertentangan dengan norma-norma sosial kemasyarakatan, seperti kriminalitas, pelanggaran terhadap norma-norma susila dan etika sosial, serta berbagai hal lain yang akhirnya berimbas ke kelompok, bukan lagi menjadi masalah individual. Kota metropolitan adalah tolok ukur sebuah "peradaban" modernitas yang nyata. Kehadiran modernitas semakin lama semakin menawarkan produk-produk fisik baru sebagai penunjang kebutuhan (gaya) hidup. Hal ini meminggirkan, meredupkan, dan bahkan mengalienasi masyarakat dengan gaya hidup tradisional yang masih memegang tradisi dan budaya yang mungkin secara diam-diam masih menyimpan nilai, kepercayaan, dan perilaku lama (Santosa, 2018:60). Perilaku lama yang dimaksud Iman adalah kebiasaan masyarakat hidup berkerabat.

Masyarakat yang masih memegang tradisi gotong-royong, saling membantu jika ada kesulitan dan jika ada hajatan adalah masyarakat yang masih memegang kuat kekerabatan. Tradisi dan budaya berkerabat membentuk individuindividu di dalam kelompok masyarakat tersebut bersikap sopan, ramah, saling menghargai, saling menyapa, dan saling membantu. Sikap tersebut menumbuhkan rasa toleransi terhadap sesama penduduk (desa), bahkan meluas pula terhadap orang-orang yang datang dan memasuki wilayah tempat mereka tinggal. Sikap ramah, rukun, sabar, sopan-santun, tulus, saling membantu terbentuk karena "keramahan" dan "keteduhan" masyarakatnya. Budaya dan tradisi semacam itu masih banyak dijumpai di desa-desa, kota-kota kecil, serta kampung-kampung. Lingkungan masyarakat yang masih memegang kekerabatan secara kuat biasanya 
mempunyai lingkungan alam yang sejuk. Alam tersebut memberi ruang nyaman bagi hati dan fisik masyarakatnya sehingga aktivitas sosial budaya orang-orang desa terbentuk dengan pola dan manajemen alamiah.

Fenomena sosial budaya masyarakat yang hidup dengan perilaku modern mengusik hati Iman Budhi Santosa. Seperti geguritan "Serere Adhuh Lae" karya Turiyo Ragilputro yang menyitir pedas perilaku anak-anak muda yang sudah melupakan budaya dan tradisi pedesaan karena mengalami gegar budaya. Maka puisi "Ziarah Tembuni" dan "Ziarah Tanah Jawa" ciptaan Iman Budhi Santosa secara persuasif mengajak mereka yang sudah teralienasi dengan budaya lokal dan tanah kelahiran untuk mengingat kembali dan peduli dengan budaya dan pranata sosial serta tradisi tempat mereka lahir, yaitu tanah Jawa.

\subsection{Jawa dan Alam Kejawaan}

Ekspresi kepengarangan Iman Budhi Santosa disarikan dari pengalaman hidup yang mereka hadapi sehari-hari. Saphir-Whorf (Wollf, 1975:23) mengatakan bahwa pengalaman utuh (total experience) individu termasuk persepsi, cara berpikir, pandangan dunia dibentuk dengan bahasanya. Bahasa menjadi peranti untuk menunjukkan ciri khas ekspresi kepengarangan. Lebih lanjut, Hetzler (dalam Wolff, 1975:22) mengemukakan bahwa bahasa berfungsi sebagai agen kontrol sosial, petunjuk sosial budaya (socio cultural index) dan catatan (seperti nama orang, sapaan, tempat, sistem kepercayaan, budaya, serta entitas yang ada dalam masyarakat). Iman Budhi Santosa menggunakan peranti indeks sosial budaya dalam "Ziarah Tembuni” dan "Ziarah Tanah Jawa". Kekhasan ekspresi menggunakan diksi dengan idiom Jawa kental mewarnai kedua puisi tersebut. Selain itu, nama-nama tanaman tradisional juga menjadi bagian ekspresi kedua puisi tersebut.

Judul "Ziarah Tanah" Jawa dan "Ziarah Tembuni” menegaskan kredo Iman Budhi Santosa dalam merekatkan kembali manusia dengan alam dan asalusulnya sehingga kata kunci ziarah menjadi pilihan untuk judul kedua puisi tersebut. Pengalaman batin dan fisik menjadi begitu kental dalam kedua puisi tersebut seakan Iman kembali bernostalgia, mengumbar memoar masa lalu dan masa kecil 
untuk menemukan kejatian manusia dalam merasakan hidup yang sebenarnya. Maka, nada (tone) kerinduan sangat dominan di kedua puisi tersebut.

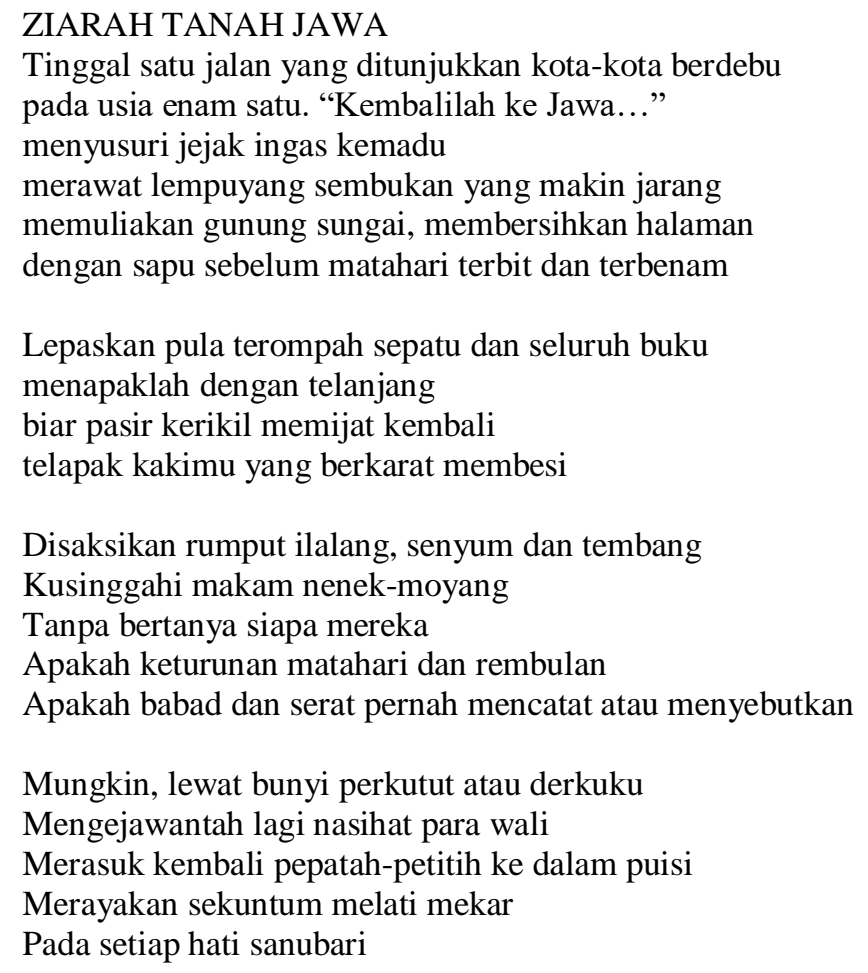

(Santosa, 2013:42)

Ketenangan dan rasa yang mendalam terasa lebih diprioritaskan oleh Iman untuk menohok pembaca supaya larut memahami ajakannya untuk kembali ke tempat asal-usul kita. Bait pertama puisi tersebut berisi "petunjuk arah" yang sudah tidak dapat lagi ditawar oleh manusia, /tinggal satu jalan yang ditunjukkan kota-kota berdebu/,/pada usia enam satu. "Kembalilah ke Jawa”/. Baris pertama dan kedua tersebut terasa mengunci "produktivitas" manusia untuk meneruskan pengembaraan mereka menjauhi tanah kelahiran. Paparan ini seakan menunjukkan dua tlatah (daerah) yang beroposisi dalam kredo ideologis tentang ketenteraman jiwa. Ketika baris /menyusuri jejak ingas kemadu/,/merawat lempuyang sembukan yang makin jarang/,/memuliakan gunung sungai, membersihkan halaman/,/dengan sapu sebelum matahari terbit dan terbenam/ dipaparkan pada bait pertama untuk menyambut dua bari awal bait tersebut, Iman ingin menunjukkan bahwa secara oposisional bahwa tlatah yang perlu ditinggalkan adalah tlatah yang tidak menjanjikan kredo ideologis tentang ketentraman jiwa. 
Berikutnya, bait dua, tiga, dan empat merupakan bait penegas mengapa kita harus kembali ke Jawa. Bait kedua pun menegaskan ajakan untuk kembali menjadi "kita sendiri" dalam arti meninggalkan segala iming-iming kebendaan yang dijanjikan oleh telatah seberang. Ungkapan /lepaskan pula terompah sepatu dan seluruh buku/,/menapaklah dengan kaki telanjang/,/biar pasir kerikil memijat kembali/,/telapak kakimu yang berkarat dan membesi/ adalah sebuah afirmasi untuk meninggalkan dunia kebendaan dan kembali ke asal-usul kita dengan kesejatian yang dipunyai manusia.

Ajakan kembali ke Jawa ini pun dilakukan oleh Iman dengan sebuah iming-iming seperti seorang ayah menjanjikan sesuatu kepada anak kecil. Penggunaan orang pertama tunggal disisipkan oleh Iman untuk menggambarkan bagaimana dia sangat merasa nyaman kembali ke Jawa, seperti dalam /disaksikan rumput ilalang, senyum dan tembang/,/kusinggahi makam nenek-moyang/,/tanpa bertanya siapa mereka/,/apakah keturunan matahari atau rembulan/,/apakah babad dan serat pernah mencatat atau menyebutkan/.

Berikutnya adalah puisi "Ziarah Tembuni” yang lebih bernarasi tentang identitas sosial budaya Jawa yang lebih terperinci dibandingkan puisi "Ziarah Tanah Jawa". Puisi ini seakan menyambut dan menjelaskan isi puisi "Ziarah Tanah Jawa". Keduanya mempunyai nada yang sama, yaitu nada kerinduan.

\footnotetext{
Ziarah Tembuni

Berkaca pada lantai pendapa, malam wangi Wijayakusuma keriput uban serentak melawan, karena di sudut dekat pot bunga berlumut, saudaraku tembuni yang kikut serta dari gua garba bunda masih tersimpan aman dan patut

Di sana masih tegak pohon mangga bapang sepasang kelapa gading dan rumpun bambu kuning ditambah tebu hitam, meniran dan kaca piring melengkapi salam sapa pagar halaman yang ramah dan hening. "Ya, aku masih di Jawa." bersama welat dan jamu menyanding pohon srigunggu, tuah tapak liman, serta dewandaru

"Tetapi, mengapa engkau merasa jadi tamu..."

Padahal, di sana masih ada makam leluhur. Ada nisan kayu batu ditatah dengan goresan paku. Mereka tak pernah lupa siapa anak cucu yang dulu nakal, suka mencuri ketela dan membakarnya malam-malam saat bulan puasa. Maka, seperti terbangun dari mimpi, kucabuti rumput teki yang berakar pada dahi mereka, yang menjalar menutup nama yang pernah mendongengkan kisah Nabi Ramayana hingga Mahabharata
} 


\begin{abstract}
Ya, di sini aku punya kisah lama
Ada perlambang pada anak panah dan gendewa

Ada ibu yang melepaskan dirimu diriku

Berguru pada tunas dan buku lebih dari Saturday

Kini, dengan keringat di dahi kucium kembali tanah itu

Bersama derit bambu kusembuhkan penat perjalanan bersepatu

Di sini engkau aku lahir, menjadi akar dan batang kayu

Di sini pula ribuan dongeng berkait menlejma biduk dan perahu.
\end{abstract}

(Santosa, 2013: 72)

Iman menggunakan "Ziarah Tembuni” untuk mengekspresikan nada (tone) kerinduan yang mendalam. Tembuni adalah plasenta atau ari-ari yang keluar dari rahim segera setelah bayi keluar dari rahim ibu. Orang Jawa menyebut tembuni sebagai kakang kawah adhi ari-ari, artinya tembuni yang berwujud daging tersebut merupakan saudara kandung si bayi. Penguatan nada kerinduan diperkuat dengan digunakannya tokoh aku untuk meyakinkan pembaca. Ibarat sebuah nada pantun, Ziarah Tanah Jawa adalah sampiran dan Ziarah Tembuni adalah isi. Nada kerinduan yang amat dalam terhadap saudara kandung sudah dimulai oleh Iman semenjak penulisan judul. Kata ziarah menunjuk pada sebuah perjalanan jauh yang sakral (KBBI: kunjungan ke tempat yang dianggap sakral atau mulia (makam)), sedangkan tembuni adalah tujuan kunjungan tersebut. Dalam nalar oposisional, tokoh aku berada jauh dari tempat tembuni tersebut dikuburkan. Kuburan tembuni adalah tanah kelahiran si aku, karena tembuni pasti dikubur, dalam budaya Jawa, di tempat atau rumah orang tua si jabang bayi.

Bait pertama dan kedua dalam puisi tersebut langsung memaparkan sebuah memoar masa lalu, refleksi atau flashback alur narasi dihantarkan melalui baris pertama dengan diksi /kaca/ sebagai sebuah cermin masa lalu, /berkaca pada lantai pendapa.../. Selanjutnya narasi tersebut secara rinci menggambarkan suasana pendapa semasa tokoh aku masih kecil mulai baris kedua bait pertama /..., karena di sudut/,/dekat pot bungan berlumut, saudaraku/,/tembuni yang ikut serta dari gua garba bunda/,/masih tersimpan aman dan patut/.

Kekuatan memoar tokoh aku diuraikan dengan jelas pada bait kedua dengan penyebutan nama-nama tumbuhan khas Jawa, seperti pohon mangga bapang, kelapa gading, bambu kuning, tebu hitam, meniran, srigunggu, tapak liman, dewa daru. Kekuatan kerinduan terhadap saudara kandung tersebut diperte- 
gas lagi dengan penyebutan bersama welat dan jamu yang menjadi ubarampe atau peralatan potong tali pusat yang berasal dari sayatan kulit bambu yang dipercaya sangat tajam melebihi pisah serta jamu sebagai minuman kesehatan bagi ibu setelah melahirkan.

Tembuni menjadi entitas yang dihadirkan pengarang untuk membuka langkah tokoh aku menemukan dan menghargai leluhurnya, bahkan menemukan ketenteraman jiwanya. Penemuan ketenteraman jiwa si tokoh aku ditunjukkan dalam pernyataannya di baris pertama bait ketiga, "Tetapi mengapa sekarang engkau merasa jadi tamu ...". Secara implisit, pernyataan tersebut menunjukkan bahwa si tokoh aku adalah aku yang mewakili rasa universal setiap orang. Kata /engkau/ adalah kunci yang menegaskan sifat keuniversalan rasa tersebut. Rasa universal tersebut diperkuat dengan gambaran makam leluhur dengan identifikasi nisan kayu batu yang ditatah dengan goresan paku. Penggambaran nada kerinduan semakin diperdalam dengan memoar masa kecil dengan baris-baris berikut /mereka tak pernah lupa/,/siapa anak cucu yang dulu nakal, suka mencuri ketela/,/dan membakarnya makam-malam saat bulan puasa/. Ingatan yang diseret ke masa kecil menunjukkan bahwa si tokoh ingin memanjakan diri secara total sebagai seorang anak yang masih lugu, karena anak akan selalu dimanja oleh orang tuanya. Ketika sekarang tokoh aku kembali lagi dengan umurnya yang telah lanjut, ingatan tersebut berubah menjadi rasa hormat. Digambarkan dalam bait ketiga dengan, /maka seperti terbangun dari mimpi, kucabuti rumput teki/,/yang berakar pada dahi mereka, yang menjalar/. Kepatuhan dan kepasrahan jiwa yang menanangkan yang telah mendewasakan si tokoh aku. Bait terakhir menyimpulkan kepasrahan, kerinduan, dan katarsis dalam jiwa si tokoh aku. /kini dengan keringat di dahi kucium kembali tanah itu/,/bersama derit bambu kusembuhkan penat perjalanan bersepatu/,/di sini engkau aku lahir, mejadi akar dan batang kayu/,/di sini pula ribuan dongeng berkait menjelma biduk dan perahu/.

Pemilihan diksi dalam idiom Jawa melalui nama-nama alamiah, seperti aktivitas tradisional, seperti menapak dengan kaki telanjang, memuliakan gunung, membersihkan halaman dengan sapu sebelum matahari terbit dan terbenam. Penyebutan nama-nama tanaman, seperti rumput ilalang, bunga melati; hewanhewan, seperti perkutut, derkuku, makam sebagai sebuah tonggak pohon kekera- 
batan mempertegas ingatan akan asal-usul tanah kelahiran manusia. Semua idiom Jawa tersebut menjadi bagian kehidupan sosial budaya keseharian orang Jawa, ingatan kolektif tradisional tentang ajaran para wali, makam, babad, serat, diangkat Iman untuk mengentalkan rasa dan nada puisi Ziarah Tanah Jawa sebagai sebuah katarsis yang diuraikan secara lebih rinci melalui Ziarah Tembuni, bahwa tujuan kehidupan bendawi, kekuasaan, martabat adalah sebuah absurditas semata. Akhirnya ingatan kolektif tentang lokalitas tradisional yang diangkat Iman akhirnya bermuara pada pengembalian rasa sejati yang berpangkal pada hati nurani yang selalu mengingat akan asal-usul, leluhur, dan alam yang mendampingi kelahiran.

Pemahaman terhadap ingatan akan asal-usul, leluhur, dan alam yang mendampingi kehidupan tersebut merupakan falsafah kebudayaan manusia. Kehidupan manusia selalu berpasangan, seperti halnya unsur-unsur di alam, ada siang-malam, langit-bumi, dan lain sebagainya. Sebagai bagian dari alam, manusia dituntut juga bertanggung jawab terhadap alam, mampu membaca tanda alam dan merawatnya (Bahardur, 2018:156). Dengan demikian relasi manusia dan alam adalah sebuah relasi mutualisma. Iman Budhi Santosa berusaha menyadarkan manusia dengan ekspresi puitisnya. Lebih kanjut, dalam kerangka pikir masyarakat Jawa ada kesadaran dan pemahaman tentang sangkan paraning dumadi atau ingat akan asal usul. Konsep kebersatuan atau ingat, manusia dengan alam dihayati secara mendalam adalah persatuan atau rekonsiliasi makhluk dengan Tuhannya (Widijanto, 2018: 111).

\subsection{Rekonsiliasi Versus Kuasa Globalisasi}

Ideologi verstehen, dalam sosiologi sastra Wolff, adalah sebuah usaha untuk memahami (verstehen) karya sastra sedekat mungkin dengan cara berpikir pengarang (Wolff,1975:6). Cara berpikir dan ekspresi pengarang menunjukkan bahwa dia mempunyai hubungan dan menjadi bagian dari dunia sosialnya, Iman Budhi Santosa dan tanah Jawa. Iman Budhi Santosa dalam pandangan verstehen hadir sebagai aktor pengalam sekaligus pengulas, dan evaluator terhadap fenomena sosial budaya yang terjadi, yaitu dalam menyikapi budaya modern dan tradisional yang dialami oleh masyarakat Jawa. 
Perlambangan (tipifikasi) yang diekspresikan oleh Iman Budhi Santosa dalam kedua puisinya terasa sederhana. Ekspresi kesederhanan yang diungkapkannya sebenarnya menyuguhkan nada kerinduan yang begitu mendalam terhadap asal-usul manusia dalam sebuah jarak estetika. Iman berupaya membuat jarak estetika dengan pembaca puisinya seminimal mungkin. Ekspresi tersebut adalah ekspresi yang mendalam berbasis memoar pribadi. Maka berbagai karya Iman selalu berupaya untuk menyodorkan kebaruan. Maksud Iman Budhi Santosa tentang kebaruan adalah kembali ke asal-usul (Santoso, 2014: 552). Hal tersebut dinalarkan oleh Iman melalui idiom-idiom Jawa dengan mengungkap latar alam, budaya etnik nusantara. Oposisi situasi begitu jelas muncul dalam paparan diksi menggambarkan sebuah kepenatan dan kerinduan akan tanah kelahiran, yang juga identik dengan ibu pertiwi, ibu kandung (kita).

\author{
Ziarah Tanah Jawa \\ Kepenatan : /kota-kota berdebu/ \\ /Usia enam satu/ \\ /Lepaskan pula terompah sepatu dan seluruh buku/ \\ /Menapaklah dengan kaki telanjang/ \\ (Santosa, 2013: 42)
}

\begin{abstract}
Ziarah Tembuni
Kerinduan: /Berkaca pada lantai pendapa.../

/Tembuni yang ikut serta dari gua garba bunda/

/Masih tersimpan aman dan patut

/Di sana masih tegak pohon mangga bapang/

/Tetapi mengapa sekarang engkau merasa jadi tamu.../

/Siapa anak cucu yang dulu nakal, .../

/Maka seperti terbangun dari mimpi, kucabuti rumput teki.../

/Ya, di sini aku punya kisah lama/

/Kini, dengan keringat di dahi kucium kembali tanah itu/

/Di sini engkau aku lahir, menjadi akar dan batang kayu/

/Kembali ke rahim Ibu, tidak ada rasa iri dan dengki/
\end{abstract}

(Santosa, 2013: 72)

Oposisi budaya modern dan tradisional dengan perlambangan yang dipaparkan tersebut menunjukkan rekonsiliasi batin bagi tokoh aku dalam kedua puisi tersebut. Rekonsiliasi tersebut menawarkan ketenteraman batin ketika tokoh aku harus menghadapi dunia modern yang dijalaninya. Ajakan Iman Budhi Santosa adalah "kembalilah dan ingatlah akan asal-usulmu, tanah kelahiran dan leluhur yang akan memberimu kekuatan untuk hidup dan berkarya membangun tanah kelahiran yang kaya". Modernitas memang menjanjikan kehidupan secara visual dan bendawi, tetapi kesiapan mental untuk menghadapinya memerlukan strategi. 
Tanah kelahiran dengan tradisi yang dipunyai menyuguhkan keluguan dan perlindungan terhadap kehidupan melalui kemapanan jiwa.

Tidak diperlukan strategi untuk membangun tanah kelahiran kita, karena semuanya adalah saudara yang kita kenal sejak kita lahir, alam, leluhur, dan rasa jiwa. Suatu bangsa yang utuh membutuhkan landasan sejarah dan tradisi, selain pembangunan di bidang politik dan ekonomi. Dengan demikian, penyadaran akan tanah kelahiran, Jawa adalah penyadaran kemanusiaan dalam kerangka tradisi dan sejarah kelahiran. Maka, rekonsilisasi terhadap tanah kelahiran (jagat alit) adalah cikal bakal rekonsiliasi terhadap bumi pertiwi Indonesia (jagat ageng). Rekonsiliasi ini pun beranalogi pada penyadaran akan pemerolehan pengetahuan, seperti pemerolehan bahasa, yaitu mengajarkan bahasa daerah terlebih dahulu baru mengajarkan bahasa Indonesia. Analogi ini digunakan untuk mengatasi kepunahan bahasa, maka strategi tersebut juga berlaku logis dalam mengatasi keterasingan bangsa Indonesia terhadap negeri Indonesia dengan merawat tradisi daerah sebagai identitas bangsa (Taib, 2015:253-255). Inilah ideologi pengarang, Iman Budhi Santosa untuk menyampaikan katarsis kepada pembaca melalui puisi "Ziarah Tanah Jawa” dan "Ziarah Tembuni”.

Ideologi rekonsiliasi dengan tanah kelahiran adalah sebuah ingatan akan kearifan lokal. Dengan pengenalan dan pemahaman terhadap kearifan lokal, maka konflik antarindividu dan kelompok dapat diredam (Simarmata, dkk., 2017:16), khususnya di jagat ageng, Indonesia. Kearifan lokal perlu kembali direvitalisasi sebagai sebuah tawaran konkret bagi mereka yang sudah "tercerabut" dari ingatan tradisi dan budaya lokal mereka. Maka, bentuk konkret rekonsiliasi mencipta dan menghadirkan arena apresiasi sastra (khususnya sastra yang bertema tentang kekerabatan, sosial, dan budaya), menghidupkan kembali ingatan akan bentukbentuk dan gaya kekerabatan yang menjadi ciri khas masyarakat Jawa melalui karya sastra. Dalam hal ini Iman Budhi Santosa mengejawantahkannya dengan mencipta puisi, puisi yang merevitalisasi ingatan untuk kembali ingat kepada tanah Jawa, tanah leluhur, tanah yang melahirkan, memelihara, dan memberi bekal hidup. Ajakan rekonsiliasi oleh Iman Budhi Santosa merupakan sebuah analogi yang berimplikasi luas, yaitu cinta pada tanah air yang berbudaya bhineka yang harus dipertahankan oleh generasi-generasi mendatang. 


\section{SIMPULAN}

Ekspresi puisi "Ziarah Tanah Jawa" dan "Ziarah Tembuni” karya Iman Budhi Santosa menggambarkan fenomena sosial budaya masyarakat Jawa yang terimbas globalisasi dan modernisasi. Akibat yang ditimbulkan adalah masyarakat semakin teralienasi dengan budaya lokal, yaitu budaya yang membesarkan mereka sejak lahir. Jagat Jawa dengan indeks sosial budaya Jawa diangkat oleh Iman Budhi Santosa sebagai sebuah analogi penggambaran bumi pertiwi, tempat kelahiran para individu yang sudah teralienasi dari budaya di tanah kelahirannya kerena modernisasi. Gambaran kepenatan perjalanan hidup (modernitas) digambarkan Iman Budhi Santosa melalui tipifikasi idiomatik Jawa dalam puisi "Ziarah Tanah Jawa”. Gambaran kerinduan akan tanah kelahiran (kekerabatan-budaya-tradisi lokal) digambarkan Iman Budhi Santosa melalui tipifikasi idiomatik Jawa dalam puisi “Ziarah Tembuni”.

Bahasa puitik Iman Budhi Santosa dalam kedua puisinya tersebut menunjukkan ideologi kepengarangannya, yaitu ajakan rekonsiliasi dengan tanah kelahiran. Rekonsiliasi adalah memulihkan hubungan persahabatan ke keadaan semula. Dalam hal ini adalah keadaan manusia yang ingat akan jati dirinya sebagai bagian dari masyarakat yang berkerabat dengan sesama dan alam sekitar. Kesadaran akan kekerabatan ini menumbuhkan kekuatan mental dan spiritual untuk sadar dan mencintai (kembali) tanah air apa adanya. Walaupun gelombang globalisasi dan modernisasi datang tak terbendung, penumbuhan rasa cinta terhadap tanah air melalui kearifan lokal, interaksi terhadap kerabat dalam budaya dan tradisi setempat harus tetap terjaga. Modernitas diidealkan berpondasikan budaya dan tradisi bangsa sendiri, Indonesia yang berbudaya bineka.

\section{DAFTAR PUSTAKA}

Bahardur, Iswadi. (2018). "Kearifan Lokal Budaya Minangkabau dalam Seni Pertunjukan Tradisional Randai”. Jentera. Jurnal Kajian Sastra. 7 (2), 145160, (C2018.

Berger, Peter L., Thomas Luckmann. (1990). Tafsir Sosial Atas Kenyataan. Risalah tentang Sosiologi Pengetahuan. Yogyakarta: LP3ES.

Devinta, Marshellena, Nur Hidayah, Grendi Hendrastomo (2015). "Fenomena Cultural Shock (Gegar Budaya) pada Mahasiswa Perantauan di Yogyakarta". Jurnal Pendidikan Sosiologi. 2015 halaman 1-15. 
Lestari, Winda Dwi, Sarwiji Suwandi, Muhammad Rohmadi. (2018). "Kaum Subaltern dalam Novel-Novel Karya Soeratman Sastradihardja: Sebuah Kajian Sastra Poskolonial". Widyaparwa, Volume 46, Nomor 2, Desember 2018. 179-188.

Purwantini (2016). "Urbanisme, Urbanisasi, dan Masyarakat Urban di Jakarta dalam Novel Senja di Jakarta”. ATAVISME, Vol.19, No.2, Edisi Desember, 2016: 162-175.

Rahmawati, Dian Lufia. (2019). JIWA PUISI. Puisi-puisi Iman Budhi Santosa. Dalam Pendekatan Psikofilosofi Berdasarkan Perspektif Ki Ageng Suryomentaram. Yogyakarta: Interlude.

Safitri, Anggun Nirmala. (2015). "Pergulatan Iman Budhi Santosa Untuk Mencapai Posisi Terkonsekrasi Dalam Arena Sastra Yogyakarta". Jurnal Poetika Vol. 2, Desember 2015. Halaman 124-131.

Santosa, Iman Budhi. (2018). Kalakanji. Kumpulan Esai Kebudayaan Sastra dan Seni. Yogyakarta: Interlude.

Santosa, Iman Budhi. (2017). Suta Nawa Dhadhap Waru. Manusia Jawa dan Tumbuhan. Yogyakarta: Interlude.

Santosa, Joko (2014). Teori Puisi Iman Budhi Santosa. Dalam Prosiding Seminar Internasional PMSI XXXVI tahun 2014. Yogyakarta: Prodi Pendidikan Bahasa dan Sastra Indonesia FKIP. Universitas Ahmad Dahlan, Yogyakarta.

Santosa, Iman Budhi. (2013). Ziarah Tanah Jawa. Kumpulan Puisi 2006-2012. Yogyakarta: interlude.

Santosa, Iman Budhi. (2012). Narasi Tembuni. Kumpulan Puisi Terbaik KSI Award 2012 Komunitas Sastra Indonesia. Jakarta: komunitas sastra Indonesia (KSI) dan Badan Pengembangan dan Pembinaan Bahasa, Kemendikbud.

Santosa, Iman Budhi. (2016). Ngelmu Iku Kelakone Kanthi Laku. Proses Kreatif Sastrawan Yogyakarta. Iman Budhi Santosa, Herry Mardianto, Latief S. Nugraha (editor). Yogyakarta: Kementerian Pendidikan Dan Kebudayaan. Balai Bahasa Daerah Istimewa Yogyakarta.

Simarmata, Henry Thomas.dkk. (2017). Indonesia Zamrud Toleransi. Jakarta: Pusat Studi Islam dan Kenegaraan Indonesia.

Satiyoko, Yohanes Adhi. (2012). "Wong Jawa" dalam geguritan "Serere Adhuh Lae" karya Turiyo Ragilputro dan "Siter Gadhing" karya Djaimin Kariyodimejo". Prosiding. Yogyakarta: Balai Bahasa Yogyakarta.

Soeroso, Amiluhur, Y. Sri Susilo. (2008). "Strategi Konservasi Kebudayaan Lokal Yogyakarta". Jurnal Manajemen Teori dan Terapan I Tahun 1, No.2 Agustus 2008. Halaman 144-161.

Supardi, Nunus. (2013). "Bianglala Budaya. Rekam Jejak 95 Tahun Kongres Kebudayaan 1918 - 2013". Jakarta: Direktorat Jenderal Kebudayaan Kementerian Pendidikan dan Kebudayaan.

Suwandi, Sarwiji. (2018). "Tantangan Mewujudkan Pembelajaran Bahasa dan Sastra Indonesia yang Efektif di Era Revolusi Industri 4.0”. Makalah yang dipresentasikan dalam Kongres Bahasa Indonesia XI yang diselenggarakan oleh Badan Pengembangan dan Pembinaan Bahasa, Kementerian Pendidikan dan Kebudayaan, Jakarta 28-31 Oktober 2018. 
Suwardana, Hendra. (2017). "Revolusi Industri 4.0 berbasis Revolusi Mental". Jati Unik, 2017. Vol.1, No.2, Hal 102-110.

Taib, Rinto. (2015). "Merawat Bahasa Sebagai Identitas Budaya Bangsa. Tafsir Identitas di tengah Dominasi Kuasa\&Universalitas (multibahasa)" dalam SEMINAR DAN LOKAKARYA LEMBAGA ADAT. Jakarta: Pusat Pengembangan Strategi dan Diplomasi Kebahasaan. Badan Pengembangan dan Pembinaan Bahasa. Kementerian Pendidikan dan Kebudayaan.

Widijanto, Tjahjono. (2018). "Dunia Halus Mistis Jawa dan Fantasi Magis Ternate dalam Godlob dan Cala Ibi." Jentera. Jurnal Kajian Sastra. 7 (1), 102-129, (C2018.

Wolff, Janet. (1975). Hermeneutic Philosophy and the Sociology of art. An approach to some of the epistemological problems of sociology of knowledge and the sociology of art and literature. London and Boston: Roultedge \& Kegan Paul 